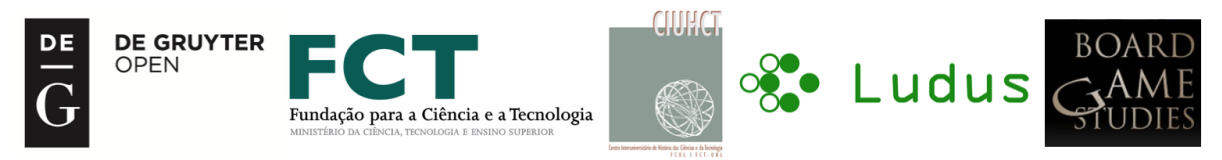

\title{
FOUR-KING CHESS WITH DICE IS NEITHER UNREALISTIC NOR MESSED UP
}

\author{
Harald Wiese* \\ University of Leipzig
}

\begin{abstract}
Kautilya's mandala model has intrigued indologists and political scientists for some time. It deals with friendship and enmity between countries that are direct or indirect neighbours. (Ghosh; 1936) suggests a close relationship between this model and Indian four-king chess. We try to corroborate his claim by presenting a stylized game-theory model of both Indian four-king chess and Kautilya's mandala theory. Within that game model, we can deal with Kautilya's conjecture according to which an enemy's enemy is likely to be one's friend. Arguably, this conjecture is reflected in the ally structure of four-king chess. We also comment on the widespread disapproval of dice in (four-king) chess.
\end{abstract}

\section{Introduction}

Chess seems to have originated in India, perhaps in the fifth century C.E 1 Chess boards used to have 8 lines and 8 columns early on and each of the two players commanded 16 pieces. The Sanskrit term for that game is caturanga which means "[boardgame] with four parts". The four parts refer to four different kind of troops in real life or pieces used in Indian chess, for example elephants, chariots, horses, and infantry (see (Scharfe; 1989 pp. 186-199) and (Bock-Raming; 1996, p. 1), respectively). Apart from these four pieces, there was a king. Let us call this sort of chess (with many different manners of

*I like to thank Maria Schetelich for pointing me to four-king chess and also for many helpful hints. Helpful comments were provided by an anonymous referee, and by Christian Alvermann, Andreas Bock-Raming, Martin Kohl, Hendrik Kohrs, Katharina Lotzen, Ulrich Schädler, Dieter Schlingloff, Jacob Schmidt-Madsen, Kerstin Szwedek, and Linda Zimmermann.

${ }^{1}$ Chess history, in particular in relation to India, is discussed by van der Linde (1874, 1881), (Murray; 1913 chapters II-IV), (Petzold, 1986 pp. 17-40), Thieme (1962, 1994), Syed (1993, 1995, 2001), (Parlett 1999), Bock-Raming (1996, 2001), (Schädler 1999), and (Schlingloff, 2009) while related dice games are treated by (Lüders, 1907).

Board Game Studies Journal 10, pp. 33-59 DOI $10.1515 /$ bgs-2016-0003 
play, to be sure) "two-king chess". A variant with four armies each consisting of 8 pieces was also in use. It is also called caturanga or, tellingly, catūrāju ("[boardgame] with four kings"). This four-king chess seems to have been played by four players, but perhaps also by two players each commanding two armies. In some versions of chess, dice are used to tell the players which pieces to move.

Most later chess historians surmise that four-king chess has developed out of two-king chess. The piority question ${ }^{2}$ is not relevant for this paper. Instead, we are concerned with a somewhat odd aspect of this debate. Fourking chess with dice is perceived negatively and has been called "unrealistic' 3 or "messed up' 4 . The criticism is directed at (I) the use of dice within (at least some versions of) this kind of chess and (II) the fact of using four armies fighting against each other. With respect to (I), van der Linde; 1874 , p. 80) had expressed his dismay at chess with dice by claiming: "Throwing dice and engaging in logical reasoning are absolutely heterogenous so that an invention with such an irreconcilable contradiction should be considered a psychological impossibility.' $\sqrt[5]{5}$ Turning to (II), we follow Maria Schetelich (personal communication) and take exception to (Thieme; 1994, p. 19) who, supporting a personal communication by Renate Söhnen, finds the following account probable: Chariots stopped to play an important role in Indian warfare and the chess piece "chariot" was eventually replaced by the chess piece "boat". With the old formation not in place any more, caturanga ("with four parts") was misunderstood in the sense of "four parties" and arising from that misunderstanding four-king chess was constructed. According to this argument, a new kind of game (four-king chess) was conceived because the

\footnotetext{
${ }^{2}$ While (Ghosh, 1936, pp. xviii-xix), Petzold, 1986, pp. 20-40), and others argue for the priority of four-king chess, other chess historians, such as (Murray; 1913, p. 75), (Thieme; 1994 pp. 18-19), or (Syed 1995, pp. 67-70) consider two-king chess the older variant.

3(Thieme, 1994 p. 19) opines that four-king chess is an unrealistic construction ("von [...] wirklichkeitsfremder Konstruktion"). He is seconded by (Syed, 1995, p. 68).

4 (van der Linde; 1881, p. 259) uses the German word "verpfuscht" and cites the Medieval pseudo-Ovidian poem "de Vetula" (edited by (Robathan, 1968)) where, in the first book, we have "cum deciis [...), qui primus lusit in illo, fedavid ludum" (Robathan; 1968, v. 654655, p. 72). The ludus is called ludus scacorum (Robathan, 1968, v. 600, p. 71)before. Thus, we can translate as "the first who has played with dice in chess has disfigured it". (Murray; 1913 p. 508) praises the poem's author's (presumably some Richard de Fournival) "condemnation of the use of dice" as being "in advance of his time". The negative attitude towards dice games was also typical of the Medieval Catholic Church, as is clear from (Murray, 1913 pp. 410-411, fn. 49, 50).

${ }^{5}$ Translated from the German original: "Würfeln und Combiniren sind hier so absolut heterogen, dass eine mit einem solchen unversöhnlichen Widerspruch behaftete Erfindung, für eine psychologische Unmöglichkeit gehalten werden muss."
} 
description of another game (two-king chess) was not as "realistic" as before. We find this unconvincing.

Most chess historians agree that chess is a war game, used for didactic purposes (see, for example, (Syed, 1995, p. 67) and also the conclusion). If so, why should we not consider four-king chess a reflection of a simple mandala model with four parties? In his effort to date four-king chess, (Ghosh, 1936 , p. xxv) makes this connection.

The mandala theory is known to us through the Arthaśastra, which was probably written by Kautilya (roughly 2000 years ago, consult (Olivelle, 2013, p. 29)) 6 ${ }^{6}$ The Sanskrit word mandala means "circle, wheel". In Kautilya's Arthaśastra it refers to a ringlike structure of countries. A king should envision his country at the center. This king is then called vijigișu or "seeker after conquest": "The whole point of being a king was to expand his territory and treasury by conquest. But, of course, all the neighboring kings were operating under the same assumption" (see Olivelle; 2013, p. 47)). Kautilya's main theoretical idea was simple and intriguing. War can only be waged with (direct) neighbors (local warfare) 7 Therefore, neighbors tend to be enemies. Also, since these enemies might be attacked from the other side, the enemies of enemies tend to be friends. While this Kautilyan conjecture surely has a lot of intuitive appeal, we are not aware of any formal model that confirms or disproves it 8 Providing the building blocks for analyzing Kautilya's conjecture is a central aim of this paper. We will see how Kautilya's conjecture relates to the question of how kings are allied in four-king chess.

Due to lack of historical evidence, the specific nature of the link between the mandala model and four-king chess cannot be ascertained. Thus we cannot argue for this strong claim: "The mandala model was developed first. In order to understand its working, four-king chess was invented." We rather

\footnotetext{
${ }^{6}$ A later exposition of mandala theory is found in the Nîtisära (see (Mitra, 1982)), a political treatise that is several hundred years younger than the Arthaśastra. A recent paper on this important text is (Singh, 2010). (Schetelich, 1997) explores the changes undergone by the concept of man dala within the Arthaśāstra and also in Dharmaśastras and other texts during the centuries.

${ }^{7}$ We do not claim that Kautilya disregards wars between non-contiguous kingdoms. After all, there may well have been stripes of land not belonging to any kingdom so that an attack does not, of necessity, have to be waged from one's own territory (or the territory of a friend). Notwithstanding this caveat, we think that local warfare is a quite natural assumption (see also (Olivelle; 2013, p. 48).

${ }^{8}$ An empirical analysis is presented by (Maoz et al. 2007) who do not, by the way, refer to the Arthaśasstra. Roughly speaking, the empirical findings are in support of the conjecture, but the authors also obtain some counterintuitive results.
} 
argue for the following weak version: "The mandala model and four-king chess show striking similarities. Four-king chess was used in order to teach Indian kings and princes some of the strategic knowledge inherent in the mandala model. $\sqrt{9}$

Thus, the aim of our paper is to defend four-king chess against Thieme, van der Linde, and others. Our paper is organized as follows. In the next section, we briefly mention the evidence of how the four armies were distributed on the chess board and on the possibility that two of these four kings were allied, fighting against the other two kings. Section 3 then presents a few quotes from Kautilya's Arthaśāstra. Section 4 develops a formal model that allows to express and analyze Kautilya's conjecture. Finally, section 5 concludes.

\section{Four-king chess with dice}

We have some evidence on how four-king chess was played. We cite from the Tithitattva (probably 16th century CE, edited and translated into German by (Weber; 1873)). All the verses cited are also found (with minor differences) in the Caturaingadipika (edited and translated into English by (Ghosh: 1936) ${ }^{10}$. The Mánasollāsa (12th century CE) ${ }^{11}$ also has a few verses on four-king chess. Of course, quite a number of lacunae remain. We now focus on those aspects important for the present paper.

\subsection{Distributing the four armies on the chess board}

The Tithitattvd ${ }^{12}$ explains how the four armies with their four kings are distinguished by color and how they are located on a chess board (see Figure 1):

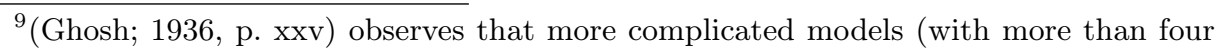
countries) are described in the Arthaśästra and elsewhere. The author then goes on to conclude that four-king chess must be older than the Arthaśästra because more complicated mandalas can be assumed to have developed from more simple ones. However, chess as a didactic version of warfare in a mandala, may well be modeled on simple rather than complicated mandalas. Also, if one finds the development from simple to more complicated structures plausible, one has an additional argument against four-king chess developing into two-king chess (against Ghosh's own conviction).

${ }^{10}$ The numbering differs because the Caturaingadipika cites from, and comments upon, the Tithitattva and other sources.

${ }^{11}$ It has been edited by Shrigondekar in 1925, 1939 and 1961. In the third volume, chess is dealt with in 5.560-623 and four-king chess in 5.615-623. The whole chess portion has been translated into German twice and independently by (Syed; 1993) and (Bock-Raming, 1996).

${ }^{12}($ Weber $1873,|2|-|3|$, p. 64)
} 


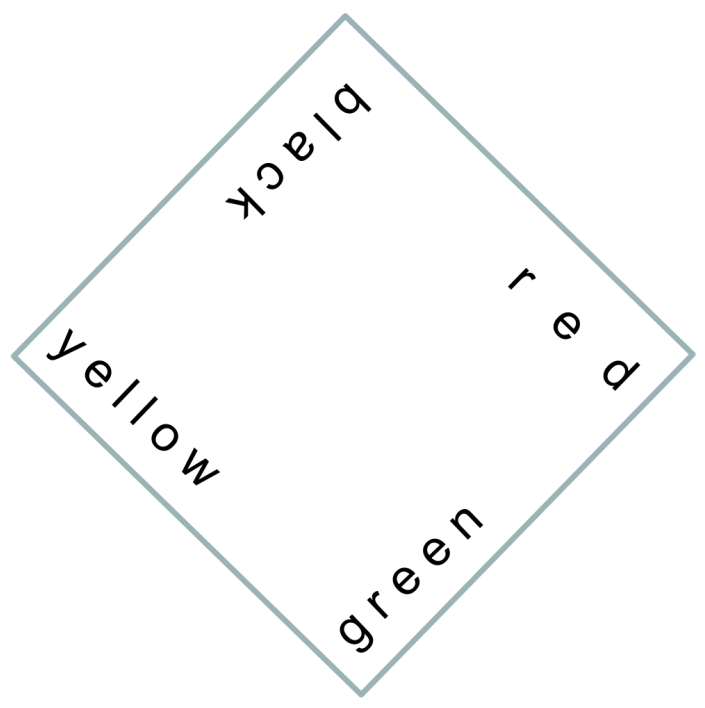

Figure 1: Four-player chess

așțau koșthān samālikhya pradakșiṇakrameṇa tu /

arunam pūrvatah krtvā dakṣine haritam balam //2///

Pārtha paścimatah pītam uttare śyāmalam balam /

... $/ / 3 / \|$

or

"Having drawn the eight fields, but having placed in clockwise fashion 13 the red in front, the green army in the south, and, Pārtha, the yellow one in the west and the black army in the north."

\footnotetext{
${ }^{13}$ Weber's German translation pulls pradakșinakramena into the absolute construction ("Acht Felder zeichne man der Reihe nach nach rechts hin") while Murray ignores pradakșinakramena and (Ghosh, 1936, v. 8) translates as "Drawing eight squares (on each side), place the pieces (balas) from the right. Put the red pieces in the east ...". Note also (Thieme, 1962, pp. 204-208) who also translates as "clockwise", but with respect to the movement of pieces.
} 


\subsection{Using the dice to determine the pieces}

After explaining how the pieces are ordered within each army ${ }^{14}$, the Tithitattva ${ }^{15}$ explains the use of dice:

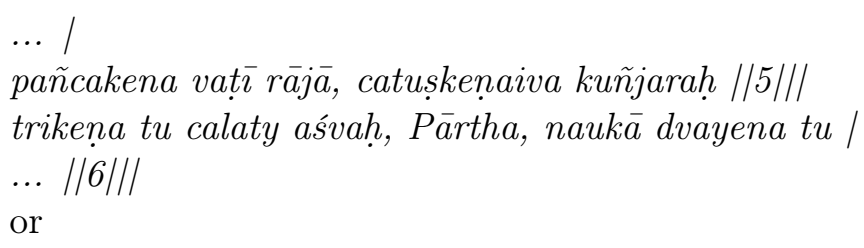

or

"With a five [on the dice] a pawn and a king move, with just a four the elephant, but with a three the horse, Pārtha, the boat, again, with a two."

(Lüders; 1907, p. 69) thinks that a paśaka was used whose four sides were indicated by the numbers 5 through 2 .

\subsection{Alliances}

It may well have been the case that the pawns (that march forward, similar to modern chess) move towards the next clockwise army (compare Figure 1). Indeed, chess historians such as (Murray; 1913, p. 69) depict the pieces on the chess board in this manner. Then, the red army should tend to attack the green one, the green one the yellow one and so forth in a clockwise fashion. Note, however, that we are not aware of any scriptual or pictorial evidence to that effect.

It may well be that Murray's (1913, p. 72) claim (regarding the Tithitattva) is related: "A game is played by four players allied in pairs. In the poem, red and yellow are allies, green and black. The nature of the alliance does not clearly transpire: it can hardly have been very cordial and sincere, when it was equally profitable to capture the ally's King or an enemy's King, and a necessity for the gain of the most profitable victory." Apart from the pawns' movements, the pairing claimed by Murray (where a king's ally is found across the diagonal) makes perfect sense from the point of view of this paper.

\footnotetext{
${ }^{14}$ Starting from the corners, one has the boat, the horse, the elephant, and the king along the respective first line and four pawns in front on the second line. This is described in (Weber, 1873, |3|-|5|, pp. 64-65). In real warfare, "the king did not usually fight in the frontline" according to (Scharfe, 1989 , p. 181).

${ }^{15}$ (Weber, $1873,|5|-|6|$, p. 65$)$
} 
This is how the ally is mentioned in the Tithitattvd ${ }^{16}$;

mitrasinhāsanam Pārtha yadārohat ${ }^{17}$ bhūpatih /

tadā sinhāsanam nāma sarvam nayati tadbalam //16//

or

"When a king, Pārtha, ascends the throne of an ally, then the so-called [procedure ${ }^{18}$ simhāsana [takes effect] and he leads his

[the ally's] whole army."

Alliances are even more explicit in the Mànasollāsa 5.615-6:

$\ldots 1$

catvāro khelakhd ${ }^{19}$ yatra tatra vyūho nirūpyate //615//

ekāntaram prakartavyam pānduram lohitam balam.. /

... $/|616 /|$

or

"Where the four players [sit], the troops are positioned. The white and the red army are to be placed alternatively ${ }^{20}$,"

Thus, the ally structure is clearly stated in the Mánasollāsa.

\section{Kautilya on war and peace}

\subsection{Dice representing fortune of war}

Taking up the two criticisms on four-king chess with dice, we need to refer to (I) the use of dice within (at least some versions of) this kind of chess and (II) the fact of using four armies fighting against each other.

\footnotetext{
${ }^{16}$ (Weber; $1873,|16|$, p. 72$)$

${ }^{17}$ Weber has yad $\bar{a}$ "rohati. It seems inconsequential whether we understand rohati or arrohati

${ }^{18}$ In (Weber, $1873,|9|$, p. 69), sinhāsana is listed among the seven pracărakas while (Ghosh 1936 15., pp. 3, 8) has prakārakas, instead. Both terms might be translated as "procedures" and mostly refer to "manners of winning".

${ }^{19}$ This is a sensible emendation for lekhakhā.

${ }^{20}$ ekāntara means the "other than the one [just placed]". (Syed 1993, p. 102) comments that the two armies belonging to one colour are to be placed diagonally. Tellingly, the same word is used by KAŚ 6.2.15 (see subsection 3.2 below).
} 
We argue that dice represent the uncertainty inherent in matters of war and peace. Kautilya was well aware of this uncertainty. Let us consider two passages from the war-and-peace part of the Arthaśastra (which we refer to by KAŚ). In KAŚ 6.2.6-12 ((Kangle; 1969, p. 165) and (Olivelle; 2013, p. 273)), we have:

mānușam nayāpanayau, daivam ayānayau |6/

daivamānuṣam hi karma lokam yāpayati /7/

adrsțakāritam daivam /8/

tasminn iștena phalena yogo 'yah, aniștenānayah /9/

drsțtakāritam mānuṣam /10/

tasmin yogaksemanispattir nayah, vipattir apanayah /11/

tac cintyam, acintyam daivam /12/

or

"Good and bad policy pertain to the human realm, while good and bad fortune pertain to the divine realm. Divine and human activity, indeed, makes the world run. The divine consists of what is caused by an invisible agent. Of this, attaining a desirable result is good fortune, while attaining an undesirable result is bad fortune. The human consists of what is caused by a visible agent. Of this, the success of enterprise and security is good policy, while their failure is bad policy. This is within the range of thought, whereas the divine is beyond the range of thought."

One may argue that this quote is not a good example of the awareness of uncertainty. After all, the divine is largely incidental to the treatise. While this is true, the quote clearly brings out the fact that humans have partial control only over matters of war and peace (and others also). The second passage is from KAŚ 9.7.8-10 ( Kangle, 1969, p. 289) and Olivelle, 2013, p. 367)):

tayoh artho na veti, anartho na veti, artho 'nartha iti, anartho 'rtha iti saṃsayah /81

śatrumitram utsāhayitum artho na veti saṃśayah /9/

śatrubalam arthamānābhyām āvāhayitum anartho na veti samśayah /10/

or

"Between these two, when one questions: 'Is this an advantage or not?' 'Is this a disadvantage or not?' 'Is this advantage actually a 
disadvantage?' 'Is this disadvantage actually an advantage?'-it is uncertainty. There is uncertainty as to whether it is an advantage or not to rouse up an ally of the foe. There is uncertainty as to whether it is a disadvantage or not to entice troops of the foe with money and honors."

\subsection{Modelling Kautilya's mandala}

Turning to (II), one needs to observe that Kautilya's mandala theory consists of two parts, the mandala and the policies to be pursued within this circle 21 First, in book 6 (immediately following the first quote from the previous section), Kautilya describes the mandalas which allow to identify enemies and friends in a straightforward manner. KAŚ 6.2.13-15 ( Kangle, 1969, p. 165) and (Olivelle, 2013, p. 274)) has

rājā àtmadravyaprakrtisaṃpanno nayasyādhiș̣thānaṃ vïigīṣuh /13/ tasya samantato mandalı̄hūtā bhümyanantarā ariprakrtih /14/ tathaiva bhümyekāntard ${ }^{22}$ mitraprakrtih /15/

or

"The seeker after conquest is a king who is endowed with the exemplary qualities both of the self and of material constituents, and who is the abode of good policy. Forming a circle all around him and with immediately contiguous territories is the constituent comprising his enemies. In like manner, with territories once removed from his, is the constituent comprising his allies."

For our paper, this is the central quotation. Its relevance is twofold:

- We have here a definition of a mandala ${ }^{23}$ In the next section, we formally define mandalas.

- These quotations are often summarized by "the enemy of my enemy is my friend". This is what we call Kautilya's conjecture.

\footnotetext{
${ }^{21}$ (Scharfe, 1989 , pp. 202-212) explains both parts within the state's foreign affairs.

22 ekantara is also found in subsection 2.3 above.

${ }^{23}$ (Scharfe 1968, p. 126) presents a linear depiction of a king's mandala. He argues that such a scheme is geared towards individual conflicts. This discussion is not relevant for the current paper.
}

Board Game Studies Journal 10, pp. 33-59 DOI $10.1515 /$ bgs-2016-0003 
Second (from book 7 onward), Kautilya expounds six gunas ("strategies"): saṃdhi ("peace pact"), vigraha ("initiating hostilities") stationary"), yāna ("marching into battle"), samśraya ("seeking refuge"), and dvaidhibhāva ("double stratagem") 25 (Olivelle, 2013, p. 659) explains the translation of guna as strategy by referring to KAS 6.2.6-12 from the previous section: While the literal meaning of gund ${ }^{26}$ is "quality or attribute", we are concerned here with the six attributes of (good) human policy. This is an important remark for us: A king may follow the recommendations given by Kautilya, but he should still be aware of the "divine" and "invisible" (the dice!) that may also feed into success or failure.

Taking up two (arguable central) strategies, we provide a game-theoretic analysis of the mandala model. We focus on "remaining stationary" and "marching into battle" and translate these actions with "not attacking" and "attacking", respectively. We are then in a position to define a game in the sense of game theory. Within this game, we can find out whether the enemy of an enemy is, indeed, a friend.

\section{$4 \quad$ Fighting involving friends and enemies}

\subsection{Neighborhood structures and fighting structures}

We now provide a formal definition of a mandala by help of the concept of a "neighborhood structure". Although we later focus on four countries, the following definitions allow to define a "neighborhood structure" for any number of countries. We express the fact that countries $i$ and $j$ are neighbors by way of the shorthand $i-j$ or $j-i$. Thus, $i-j=j-i$.

Definition 1. Let $I=\{1, \ldots, n\}$ be a set of $n$ countries. A neighborhood structure $N$ on $I$ is a subset of $I^{(2)}:=\{i-j: i, j \in I, i \neq j\}$.

- By $N(i)=\{i-j: j \in I, i-j \in N\}$ we understand the set of links that country $i$ entertains under the neighborhood structure $N$.

\footnotetext{
${ }^{24}$ (Olivelle, 2011) convincingly defends his understanding of vigraha ("initiating hostilities") versus yāna ("marching into battle"). He writes: "... a state of vigraha may not result in actual fighting, but rather weaken the enemy by one's ability to resist his attacks and by destroying his sources of income, much like today's special operations" (p. 135).

${ }^{25}$ See KAŚ 7.1 .2 ((Kangle, 1969, p. 168) and (Olivelle, 2013, p. 277))

${ }^{26}$ Literally, KAŚ 7.1 .1 (introducing the list) reads sạdgunyasya prakrtimandalam yonih ( Kangle 1969, p. 168)), translated as "The basis of the sixfold strategy is the circle of constituents" by (Olivelle, 2013, p. 277).
} 


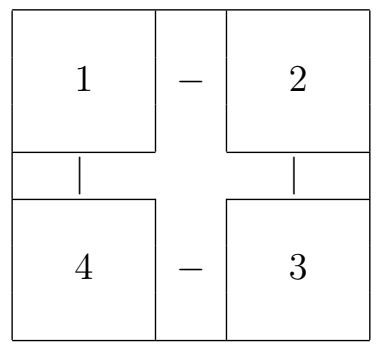

Figure 2: A symmetric four-country neighbourhood structure

- A fighting structure $F$ on $I$ is a subset of $N$. The set of fighting structures is denoted by $\mathfrak{F}$.

According to this definition, there are $n$ countries. Every particular pair $i-j$ (or $j-i$, which means the same) of countries $i$ and $j, i \neq j$ belongs to $I^{(2)}$. There may (but need not) exist a common border between $i$ and $j$. If $i$ and $j$ are indeed neighbors, $i-j$ belongs to the neighborhood structure $N$. In the absence of airplanes, fighting can occur only between neighbors. Therefore, a fighting structure $F$ has to be a subset of the neighborhood structure $N$. This means that every fighting pair $i-j$ is made up of countries $i$ and $j$ that are neighbors 27

A four-country case is depicted in Figure 2, It is chosen for the similarity with the chess board in Figure 1. Formally, we have the neighborhood structure $N=\{1-2,2-3,3-4,4-1\}$ where countrys 1 and 3 are not neighbors and 2 and 4 are not neighbors.

\subsection{Friends and enemies}

We assume that countries can evaluate fighting structures by foreseeing the likely outcomes. We capture this idea by presupposing, for every country $i$, a payoff function

$$
p_{i}: \mathfrak{F} \rightarrow \mathbb{R}
$$

This means that country $i$ attaches a real number to each fighting structure $F$ from $\mathfrak{F}$. A higher number indicates that the fighting structure is better for country $i$. Here, payoff is just a word that stands for the advantages and

\footnotetext{
${ }^{27}$ (Maoz et al. 2007, pp. 104-105) define enmity networks and alliance networks which allow elegant computations of concepts like "enemy of enemy", "friend of enemy", or "enemy of friend". They do not restrict attention to local warfare. See our remark to local warfare in the introduction.
} 
disadvantages for the king of being engaged in a fighting structure. It may be measured in terms of land won or lost (more on this matter later).

We can now define the Kautilyan concepts of friendship (mitra means "friend" or "ally") and enmity (ari is "enemy"). Of course, Kautilya's understanding of friendship and enmity is a fluctuating one (see our remark in the conclusion). A friend has two characteristics. First, a friend is somebody against whom you do not fight. Second, you like to help a friend:

Definition 2. Let I be a set of countries with fighting structure F. For three countries $i, j$, and $k$ assume

(a) $i-j \notin F$,

(b) $j-k \in F$,

(c) $i-k \in N \backslash F$.

Country $i$ is called a friend of $j$ against $k$ at $F$ if

$$
p_{i}(F \cup\{i-k\})>p_{i}(F)
$$

holds.

In the above definition, the meaning of (a) through (c) is given by

(a) $i$ and $j$ do not fight each other,

(b) $j$ is engaged in a fight against $k$,

(c) $i$ and $k$ are neighbors, but do not actually fight against each other.

Then, country $i$ is called a friend of $j$ against $k$ at $F$ if $i$ likes to start fighting against $k$ (thus helping his friend $i$ against his friend's enemy $k$ ).

Similarly, one can be an enemy in two ways. Either you actually fight him or you like to do so:

Definition 3. Assume countries $i, j$ with $i-j \in N$. Country $i$ is called an enemy of country $j$ if one of two conditions hold:

- either $i$ fights against $j(i-j \in F)$,

- or, if $i$ does not fight $j$, she would like to do so:

$$
i-j \notin F \Rightarrow p_{i}(F \cup\{i-j\})>p_{i}(F) .
$$

Taking up the fighting structure depicted in Figure 2, country 1 is never a friend of country 2. This is due to the fact that 1 cannot attack 3 . Also, country 1 is never an enemy of country 3 . We think that these claims are in line with Kautilyan thought. 


\subsection{Strategies and equilibria}

We now proceed to examine Kautilya's conjecture in a game-theoretic manner 28 Mirroring the Kautilyan actions "remaining stationary" and "marching into battle", we let every country decide which of its neighbors it wants to attack. We call the tuple of attack decisions a strategy. Second, we determine the fighting structure that results from these attack decisions. It is called an "induced fighting structure". We find it natural to assume that two countries fight against each other if one of them attacks the other or both attack each other.

Definition 4. Let I be a set of countries. Country i's strategy $s_{i}$ is a tuple with $|N(i)|$ entries where, for each $i-j \in N(i)$ (i.e., each of $i$ 's neighbors) we have either $i \rightarrow j$ ( $i$ attacks $j$ ) or $i \nrightarrow j$ ( $i$ does not attack $j)$. Let $s=\left(s_{1}, \ldots, s_{n}\right)$ be a tuple of strategies (also known as strategy combination), one strategy for each country. Then, the induced fighting structure $F(s)$ contains $i-j$ if $i \rightarrow j$ or $j \rightarrow i$ hold.

$B y s_{-i}$ we denote the strategy combination for all countries except country $i$, i.e., $s_{-i}=\left(s_{1}, \ldots, s_{i-1}, s_{i+1}, \ldots, s_{n}\right)$. Let $S$ denote the set of strategy combinations.

For example, in Figure 2, country 1 has four strategies:

- country 1 attacks both neighboring countries: $(1 \rightarrow 2,1 \rightarrow 4)$

- country 1 attacks country 2 , but not country $4:(1 \rightarrow 2,1 \nrightarrow 4)$

- country 1 attacks does not attack country 2, but attacks country 4: $(1 \nrightarrow 2,1 \rightarrow 4)$

- country 1 does not attack any country: $(1 \nrightarrow 2,1 \nrightarrow 4)$

Strategy combinations and the resulting fighting structures can be depicted in an intuitive manner. Figure 3 stands for the strategy combination $s=\left(s_{1}, \ldots, s_{4}\right)$ with

$$
\begin{aligned}
& s_{1}=(1 \rightarrow 2,1 \rightarrow 4), \\
& s_{2}=(2 \nrightarrow 1,2 \rightarrow 3), \\
& s_{3}=(3 \nrightarrow 2,3 \nrightarrow 4), \\
& s_{4}=(4 \rightarrow 1,4 \nrightarrow 3)
\end{aligned}
$$

\footnotetext{
${ }^{28}$ The interested reader can consult any one of the many textbooks on game theory, for example parts 1 and 2 in (Gibbons, 1992) or chapter 3 in (Dixit and Skeath; 1999).
} 


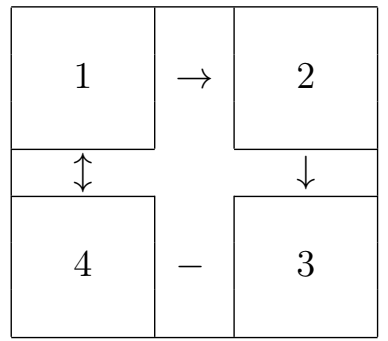

Figure 3: An induced fighting structure

and for the induced fighting structure

$$
F(s)=\{1-2,2-3,4-1\}
$$

The following definition prepares the ground for the application of game theory. So far, we have payoff functions $p_{i}: \mathfrak{F} \rightarrow \mathbb{R}$ that have the set of fighting structures as the domain. We need utility functions that have the set of strategy combinations as their domain. These utility functions are obtained via the induced fighting structures:

Definition 5. We define a utility function $u_{i}: S \rightarrow \mathbb{R}$ on $S$ by $u_{i}(s)=$ $p_{i}(F(s))$.

Thus, a utility function $u_{i}$ uses strategy combinations as input. Here is the standard definition of a game-theoretic equilibrium (often also called Nash equilibrium):

Definition 6. A strategy combination $s^{*}$ obeying

$$
u_{i}\left(s_{i}^{*}, s_{-i}^{*}\right) \geq u_{i}\left(s_{i}, s_{-i}^{*}\right)
$$

for all countrys $i \in I$ and all strategies $s_{i} \in S_{i}$ is called an equilibrium.

Thus, an equilibrium $s^{*}$ is defined by the following property: No country $i \in I$ gains by not choosing $s_{i}^{*}$ if the other countries choose $s_{-i}^{*}$. Differently put, unilateral deviation does not pay.

Definition 7. The strategy combination given by $i \rightarrow j$ for all $i, j \in I$ with $i-j \in N$ is called the trivial equilibrium.

Note that the trivial equilibrium is an equilibrium. Indeed, if only one country deviates, the fighting structure is not changed. Therefore, no country's payoff changes if that country alone stops attacking one or several of its neighbors. 


\subsection{Payoffs}

In order to find additional equilibria (apart from the trivial one), we need to define specific payoff functions

$$
p_{i}: \mathfrak{F} \rightarrow \mathbb{R}, i \in I
$$

We assume that the payoffs obey the following assumptions:

- The size of each country is 1 . This is the basic payoff and fighting power.

- If a country wins against another country, the winning country takes over the territory of the losing one.

- If several winning countries are involved, the losing country's territory is split evenly between the winning ones. This assumption is in line with Kautilya's recommendation to "urge a neighboring ruler to march into battle after concluding a pact, saying, 'You should march in this direction, and I will march in that direction. The spoils shall be equal' "(Olivelle; 2013, p. 292; 7.6.2-3). (Note that Kautilya refers to a different neighborhood structure where three countries are adjacent to each other.)

- If a country is involved in two or more fights, its fighting power is split evenly.

- The fighting powers of several attackers are added. The relative fighting power determines the winner. If the fighting power is the same, the outcome is a "draw".

- Fighting is costly. For each fight, the fighting power is reduced by $\delta>$ 0 . We assume that the cost of fighting is relatively small in comparison to a country's basic payff and fighting power of 1 and let $\delta<\frac{1}{2}$.

- Basically, payoff equals fighting power. But each country prefers weaker neighbors to stronger ones. $\varepsilon>0$ stands for the advantage of being stronger than neighbors while $-\varepsilon<0$ represents the disadvantage of being weaker.

Focusing on our four-country example, these payoff assumptions can be translated into the following payoff function for country 1 (with analogous 
payoffs for the other countries):

$$
p_{1}(F)= \begin{cases}1, & F=\emptyset \\ 1+\varepsilon, & F=\{2-3\} \text { or } F=\{3-4\} \\ 1-\varepsilon, & F=\{2-3,3-4\} \\ 1-\delta, & F=\{1-2,3-4\} \text { or } F=\{1-4,2-3\} \text { or } F=N \\ 1-\delta-\varepsilon, & F=\{1-2\} \text { or } F=\{1-4\} \\ \frac{3}{2}-\delta+\varepsilon, & F=\{1-2,2-3\} \text { or } F=\{1-4,3-4\} \\ 0, & F=\{1-2,1-4\} \\ 0, & F=\{1-2,1-4,2-3\} \text { or } F=\{1-2,1-4,3-4\} \\ 2-\delta, & F=\{1-2,2-3,3-4\} \text { or } F=\{1-4,2-3,3-4\}\end{cases}
$$

where (i) through (ix) can be seen from

(i) no fighting

(ii) two other countries fight

(iii) 3 loses against 2 and 4

(iv) all neighbors fight

(v) 1 fights against 2 or 4

(vi) 1 joins 3 to win against 2 or 4

(vii) 1 loses against 2 and 4

(viii) 1 and 2 lose, or 1 and 4 lose

(ix) 1 and 4 win, or 1 and 2 win

For example, consider the second line where two other countries $(2$ and 3 , or 3 and 4) fight. There is a draw between them and they suffer the costs of fighting $\delta$. Hence, country 1 is stronger than the fighting pair of countries and his future fighting power is $1+\varepsilon$. In line (vi), country 1 joins country 3 to attack country 2 (or country 4 ). 1 and 3 then share country 2 's (or country 4's) territory. In the last line, both countries 2 and 3 (or both countries 3 and 4 ) lose so that country 1 obtains one extra full territory.

\subsection{Identifying friends and enemies}

We now present two theorems for the four-country case. First, we identify friends and enemies for this particular neighborhood structure. Second, we list all the equibria. The proofs of the theorems are found in the appendix.

Theorem 1. Assume the symmetric four-country structure together with the payoff $p_{1}$ given above and with $\varepsilon>\delta<\frac{1}{2}$. We find:

Board Game Studies Journal 10, pp. 33-59 DOI $10.1515 /$ bgs-2016-0003 
A Country 1 is a friend of country 3 against 2 (against 4 ) at $\{2-3\}$ (at $\{3-4\})$ by $\delta<\frac{1}{2}, 29$

B Country 1 is an enemy of country 2 (of country 4 ) at $\{2-3\}$ (at $\{3-4\}$ ) by $\delta<\frac{1}{2}$,

C Country 1 is a friend of country 3 against 2 (against 4 ) at $\{2-3,3-4\}$ by $\delta<1+\varepsilon(1$ turns against either 2 , or 4$)$,

D Country 1 is an enemy of 2 (of 4 ) at $\{2-3,3-4\}$ by $\delta<1+\varepsilon$ (1 turns against either 2 , or 4 ),

E Country 1 is not a friend of country 3 against 2 at $\{1-4,2-3,3-4\}$ (or against 4 at $\{1-2,2-3,3-4\}$ ),

$\mathbf{F}$ Country 1 is not an enemy of country 2 (or country 4 ) at $F=\emptyset$.

Is the enemy of my enemy my friend? Consider the fighting structure $\{2-3\}$. Then, 1 is a friend of 3 against 2 (see A) and an enemy of 2 (see B). In that situation, the enemy of country 1 's enemy is a friend. We can argue in a similar manner for the fighting structure $\{3-4\}$. However, E shows an example where Kautilya's conjecture does not hold:

- 4 is 1 's enemy by $1-4$,

- 3 is 4 's enemy by $3-4$, but

- 3 is not 1's friend because 1 is not prepared to attack 2 .

Turn now to $\mathrm{C}$ versus $\mathrm{D}$ at fighting structure $F=\{2-3,3-4\}$. If country 1 is a friend of country 3 against 2 at $F$, country 1 is an enemy of country 2. Again, the enemy of country 1's enemy is her friend.

Let us now report the equilibria for the symmetric four-country example, some of which are asymmetric:

Theorem 2. In the symmetric four-country structure together with the payoff function $p_{1}$ and similarly for $p_{2}$ through $p_{4}$ and with $\varepsilon>\delta<\frac{1}{2}$, we have 20 equilibria:

a) the trivial equilibrium $s^{*}$ leading to $F\left(s^{*}\right)=N$,

b) the no-attack equilibrium $s^{*}$ given by $F\left(s^{*}\right)=\emptyset$,

\footnotetext{
${ }^{29}$ For $\delta>\frac{1}{2}$, country 1 would not like to attack country 3 at $\{2-3\}$ and hence, country 1 would not be a friend of country 3 against 2 at $\{2-3\}$.
} 

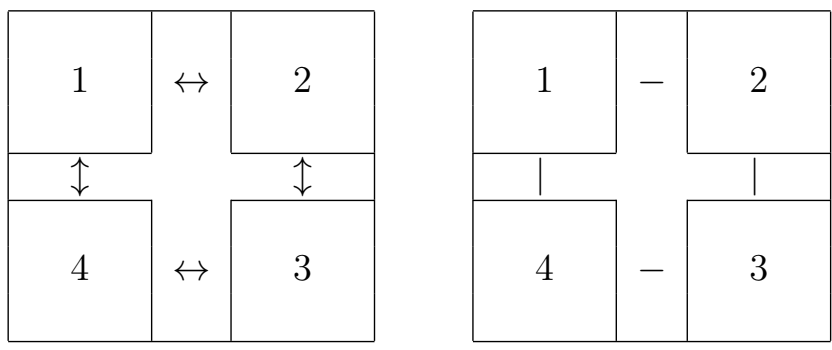

Figure 4: Allout fighting and peace

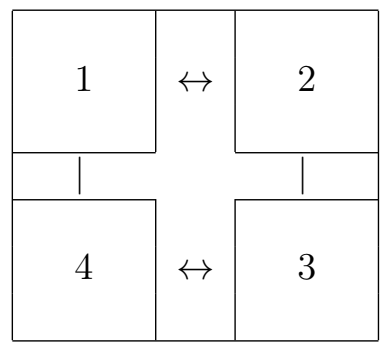

Figure 5: Two fighting pairs

c) the equilibrium $s^{*}$ with fighting pairs $1-2$ and $3-4$ resulting from mutual attacks given by

$$
\begin{aligned}
& s_{1}^{*}=(1 \rightarrow 2,1 \nrightarrow 4), \\
& s_{2}^{*}=(2 \rightarrow 1,2 \nrightarrow 3), \\
& s_{3}^{*}=(3 \nrightarrow 2,3 \rightarrow 4), \\
& s_{4}^{*}=(4 \nrightarrow 1,4 \rightarrow 3)
\end{aligned}
$$

together with the analogous equilibrium $s^{*}$ with two fighting pairs $1-4$ and $2-3$,

d) the $2 \times 2=4$ asymmetric equilibria $s^{*}$ given by $F\left(s^{*}\right)=\{1-2,2-3,3-4\}$ and $2 \rightarrow 3$ and $3 \rightarrow 2$, where $1-2$ (and also $3-4$ ) may come about by both countries attacking or country 1 attacking country 2 (country 4 attacking country 3 ), together with the analogous $3 \times 4=12$ equilibria with no fighting between 1 and 2, 2 and 3 , or 3 and 4 , respectively.

A few comments on these equilibria are in order. a) We have mentioned the trivial equilibrium in section 4.3. It is depicted in the left-hand side of Figure 4. b) The no-attack equilibrium or "peace" is a strategy combination where no country attacks any other (see the right-hand side of Figure 4). If 


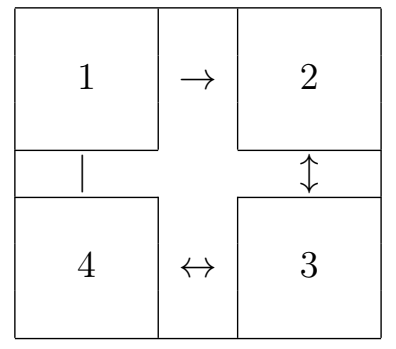

Figure 6: The horseshoe equilibrium

one country alone attacks any one country, the attacking country is worse off because his payoff is $1-\delta-\varepsilon<1$ (compare (v) and (i) in $p_{1}$ above). If one country attacks both its neighbors, its payoff is reduced to zero (see (vii) in $p_{1}$ ). c) Similar to the trivial equilibrium, we can have mutual attacks by disjoint pairs of countries (see Figure 5). Payoffs are $1-\delta$ for all countries (see (iv) in $p_{1}$ ). If 1 attacks 2 and 2 attacks 1 , neither of them can stop fighting by a unilateral action. If, in that situation, 1 attacks not only country 2 , but also its other neighbor 4 , the fighting structure $F=\{1-2,1-4,3-4\}$ results, again with zero payoff for country 1 (see (viii) in $p_{1}$ ). d) It is not difficult to see that fighting structures like $\{1-2,2-3,3-4\}$ can also be upheld in equilibrium. This horseshoe equilibrium is depicted in Figure 6 . Here, countries 2 and 3 fight attack each other and are attacked from their other respective neighbors. Country 1 , together with country 4 , manages to overwhelm countries 2 and 3 (see (ix) in $p_{1}$ ). It does not matter whether the overwhelmed countries also attack. In the figure, country 3 attacks country 4 , while country 2 does not attack country 1 .

As in E of theorem 1, equilibria such as d) are in some contrast to Kautilya's conjecture. On the one hand, country 1 attacks his direct neighbor 2 (i.e., 1 is a friend of country 3 against 2). While seemingly in line with Kautilya's conjecture, matters are really more complicated: by not attacking country 4, country 1 indirectly (with the help of 4) also attacks country 3 . On the other hand, country 1 does not attack his direct neighbor 4 (i.e., 1 is not a friend of country 3 against 4 ). Note that his last observation does not openly contradict Kautilya's conjecture because 1 is not 4's enemy.

\section{Conclusions}

The chess historian (Syed; 1995, pp. 69-70) summarizes her point of view in the following manner (the numbering is added by the current author): 
1. The oldest caturanga was of the two-king variety.

2. It served the didactic purpose of practicing war strategies.

3. Dice were not used, intelligence alone determined the outcome.

4. In due time, onlookers wished to join and hence four-king chess was invented.

5. This chess for four players was a popularized variant, did not (necessarily) belong to the court anymore and did not (necessarily) serve the didactic purpose of teaching strategy in peace and war.

(Syed; 1995, p. 70) comments: "When [four-king chess] was not about teaching the art of war any more, the cognitive ability could be combined with the contingency of dice."

While we do not wish to argue in favor or against the development sketched by Syed, we do raise objections against her comment. In our mind, the use of dice stands for an important aspect of managing war and peace. Repeating Kautilya's (and Olivelle's words): the divine realm, good and bad fortune, the invisible, what is beyond the range of thought, uncertainty. With respect to dice, we sympathize with (Schädler; 1999, p. 145) who criticizes the attitude pioneered by van der Linde according to which chess as a pure game of strategy is considered as intellectually and morally superior above chess with dice.

It is important to remember that the dice outcomes could be related to spellpower or to dexterity (see, for example, (Lüders; 1907, pp. 4-9, 29, 5760)) rather than to mere luck. One might conjecture that a king or any other army ruler might try to get the particular parts of the army in motion, but that he may fail sometimes. The dice (that regulate whose pieces to move) might stand for this problem? Jacob Schmidt-Madsen (private communication) criticizes this viewpoint: "That dice can be considered a representation of daiva is certainly a well-attested fact - as seen, for example, in the religious game of snakes and ladder $\$ 30$ — but their apparent use in four-handed chess has always struck me as a litte odd. Rolling a die to determine which piece is allowed to move smacks more of gambling than of daiva to me (if I may be allowed to distinguish between the two). I mean, which army general would not have control over the movement of his troops? Would not the daivic interpretation be more plausible if it was applied to the outcome of

\footnotetext{
${ }^{30}$ Snakes and Ladders is a children's game with dice that is "derived from a traditional Indian game of some antiquity" according to (Topsfield, 1985, p. 203).
} 
conflicts between pieces, or at least to the span of their movement as in most other dice-controlled board games?" These arguments are surely convincing. However, the rules of games (as they develop over time) have finally to be fixed in a manner as to make playing satisfactory. Since we do not understand the rules of four-king chess sufficiently well, we cannot exclude that the specific use of dice just served that purpose better than other uses.

Leaving the issue of dice, we mention the possibility (argued for by (Syed; 2001, pp. 10-11, 52)) that a didactic model, a sort of "Kriegsübung im Sandkasten", which also carried the name caturanga, formed a connecting link between real-world warfare and two-king chess. (Schlingloff; 2009, p. 677) contradicts. One of his arguments is that the movements of chess pieces do not relate to the tactical manoeuvres on the battlefield. That is surely true. But the more general ideas of how to position troups or of how to deal with enemies and allies in situations of more than two kings may still hold, on a chess board as on a battlefield.

Jacob Schmidt-Madsen (private communication) notes that the game was not, perhaps, developed as a reflection of Kautilya's theory. More generally, (Holländer; 1994, pp. 19-24) postulates that chess does not (necessarily) reflect cultural or social circumstances. Relatedly, (Burckhardt; 1969) points out that chess may symbolize heavenly bodies, four seasons, the dualism inherent in yin and yan etc. In the same vein, (Schädler; 2005, pp. 256-264) argues that board games in ancient civilizations are typically otherworldly oriented and that an Indian war game caturanga would be an outlier (calling out for an explanation). If, then, chess was not meant to reflect warfare, why would the pieces have an apparent link with Indian troups? (Schädler; 2005, pp. 264-265) advances the interesting thesis that this was done for mnemotechnical reasons. The different kinds of moves could easily be remembered by linking them to specific troups. There is, in our mind, no way to come to a definite answer. Whether or not otherworldly motives were crucial initially to bring Indian chess about is not really important for this paper and for the modest thesis defended here. Again, once a game is played the rules develop not only in line with a symbolic meaning (that may change over time) but certainly also in a manner to make playing satisfactory.

A central concern of this paper is Thieme's dictum that four-king chess is "von [...] wirklichkeitsfremder Konstruktion". We support Ghosh's thesis that Indian four-king chess reflects Kautilya's mandala model. Indeed, fourking chess is as "unrealistic" as formal models in economics and elsewhere tend to be. It was deemed to be realistic enough so that princes could be taught the tricks of coping with friendly and unfriendly countries. In a similar manner, (Wiese, 2012) claims that Indian princes were meant to 
learn backward induction by way of animal tales.

According to our game-theoretic analysis, terms like friend or enemy are defined only in terms of payoff (land to be occupied, power, ...). This way of thinking, however, is not foreign to Hindu political thought. This is clear from nearly every page of the Arthaśāstra. (Zimmer, 1969, p. 89) observes that Indian political thought was characterized by "cold-blooded cynical realism and sophistication". He also finds that "ancient Hindu political wisdom" brings about "the cold precision of a kind of political algebra, certain fundamental natural laws that govern political life, no matter where" (p. 90). To us, Zimmer's remarks are fitting for both the actions recommended within the mandala model and for the use of game theory. Similarly, in a comment on mitrasiṃhāsana (see section 2.3), (Weber; 1873, p. 72) observes "an unfaithful politics of Indian chieftains" (German: "treulose Politik indischer Fürsten").

The formal parts of our paper provide the instruments to discuss Kautilya's mandala theory. Loosely speaking, Kautilya's conjecture holds most of the time. This is interesting by itself and also relevant to four-king chess. Apparently, the ally is found across the diagonal, in line with Kautilya's conjecture.

Our simple formal model necessarily falls short of Kautilya's mandala theory in many respects, some of which we like to point out:

1. Kautilya's mandala theory is clearly dynamic in nature. We try to capture the gist of his theory by way of a static model, where $\varepsilon$ reflects the dynamic aspects. Still, a formal dynamic model would do more justice to Kautilya and might bring out results that our static version suppresses. In particular, a dynamic model will reveal how friendship may turn into enmity.

2. While we define a general framework within which Kautilya's mandala theory can fruitfully be analyzed and discussed (or so we flatter ourselves), we surely do not cover all important aspects even in a static model. For example, middle and neutral kings play an important role in Kautilya's thinking. Future research may take up these complicating factors as well as neighborhood structures with uneven fighting power. 


\section{Appendix}

\section{A Proof of theorem 1}

In order to show how the proofs work, we present a few examples.

A Applying Definition 2, country 1 is a friend of country 3 against country 2 at $\{2-3\}$ because

$$
\begin{aligned}
& 1-3 \notin F(\text { we even have } 1-3 \notin N) \\
& 2-3 \in F(\text { we even have } F=\{2-3\}) \\
& 1-2 \in N, 1-2 \notin F
\end{aligned}
$$

and

$$
p_{1}(\{2-3\} \cup\{1-2\})=\frac{3}{2}-\delta+\varepsilon>1+\varepsilon=p_{1}(\{2-3\})
$$

holds. The inequality follows from $\delta<\frac{1}{2}$.

D Applying Definition 3, country 1 is an enemy of 2 at $\{2-3,3-4\}$ because 1 does not fight 2, but would gain from doing so:

$$
p_{1}(\{2-3,3-4\} \cup\{1-2\})=2-\delta>1-\varepsilon=p_{1}(\{2-3,3-4\}) .
$$

E Applying Definition 2, 1 is not a friend of country 3 against 2 at $\{1-4,2-3,3-4\}$.

While the conditions

$$
\begin{aligned}
& 1-3 \notin F(\text { we even have } 1-3 \notin N) \\
& 2-3 \in F \\
& 1-2 \in N, 1-2 \notin F
\end{aligned}
$$

are met, country 1 prefers not to join the fighting by

$$
p_{1}(N)=1-\delta<2-\delta=p_{1}(\{1-4,2-3,3-4\}) .
$$

The other claims can be shown in a similar fashion. 


\section{B Proof of theorem 2}

a) We show in the main text (after Definition 7) that the trivial equibrium (where every country attacks each of its neighbors) is an equilibrium.

b) If no country attacks any other country, the payoff for each country is 1. Unilaterally attacking one country leads to the smaller payoff of $1-\delta-\varepsilon$. Attacking two countries is even worse, resulting in payoff 0 .

c) Under the c) equilbria, each player has the payoff $1-\delta-\varepsilon$. Deviating does not pay. Consider country 1.

- If 1 stops attacking country 2, that does not change the resulting fighting structure.

- If 1 decides to attack both 2 and 4, country 1 (together with country 4) gets a payoff of 0 .

- If 1 decides to not attack 2 , but to attack 4 instead, its payoff is the same as under the previous bullet item.

d) The set-up here is the fighting structure $\{1-2,2-3,3-4\}$ that results from countries 2 and 3 attacking each other. It is not relevant whether $1-2$ or $3-4$ result from unilateral or from mutual attacks. In this situation, the payoffs for the winners 1 and 4 are $2-\delta$ and the payoff for the loosers are 0. Observe:

- Due to the mutual attack between countries 2 and 3, their payoff does not change if one of them decides not to attack.

- If country 2 , does not attack country 1 , country 1 might attack 4 rather than 2 . In that case, country 1 's payoff stays at $2-\delta$. If country 2 attacks country 1 , country 1 can only change the fighting structure by attacking country 4 . However, that would lead to the fighting structure $N$ and reduce country 1's payoff from $2-\delta$ to $1-\delta$.

Since the other countries situations are symmetric, the d) equilibria are confirmed.

Note, finally, that no further equilibria exist. 


\section{References}

Bock-Raming, A. (1996). Mānasollāsa 5,560-623: Ein bisher unbeachtet gebliebener Text zum indischen Schachspiel, übersetzt, kommentiert und interpretiert, Indo-Iranian Journal 39: 1-40.

Bock-Raming, A. (2001). Das 8. Kapitel des Hariharacaturanga: ein spätmittelalterlicher Sanskrittext über eine Form des "Großen Schachs", Board Game Studies 4: 85-125.

Burckhardt, T. (1969). The symbolism of chess, Studies in Comparative Religion 3: 91-95.

Dixit, A. and Skeath, S. (1999). Games of Strategy, W. W. Norton \& Company.

Ghosh, M. (1936). Śūlapāni's Caturangadipikā. A Manual of Four-handed Chess, Metropolitan Printing and Publishing House, Calcutta.

Gibbons, R. (1992). A Primer in Game Theory, Harvester Wheatsheaf, New York et al.

Holländer, H. (1994). Thesen zur Früh- und Vorgeschichte des Schachspiels, HOMO LUDENS, Band IV, pp. 17-28.

Kangle, R. P. (1969). The Kautiliya Arthashastra, Part I: Sanskrit text with a glossary, 2 edn, Bombay University. [first edition from 1961, second edition reprinted 1992 by Motilal Banarsidass (Delhi)].

Lüders, H. (1907). Das Würfelspiel im alten Indien, Vol. Neue Folge Band IX of Abhandlungen der königlichen Gesellschaft der Wissenschaften zu Göttingen. Philologisch-historische Klasse, Weidmannsche Buchhandlung, Berlin.

Maoz, Z., Terris, L. G., Kuperman, R. D. and Talmud, I. (2007). What is the enemy of my enemy? causes and consequences of imbalanced international relations, 1816-2001, Journal of Politics 69: 100-115.

Mitra, S. (1982). The Nitisara, or The Elements of Polity by Kamandaki, The Asiatic Society, Calcutta.

Murray, H. J. R. (1913). A History of Chess, Oxford University Press, London.

Board Game Studies Journal 10, pp. 33-59 DOI $10.1515 /$ bgs-2016-0003 
Olivelle, P. (2011). War and peace: Semantics of samdhi and vigraha in the arthasastra, in B. Tikkanen and A. M. Butters (eds), Purvaparaprajnabhinandanam East and West, Past and Present, pp. 131-139.

Olivelle, P. (2013). King, Governance, and Law in Ancient India: Kautilya's Arthasastra, Oxford University Press.

Parlett, D. (1999). The Oxford History of Board Games, Oxford University Press.

Petzold, J. (1986). Schach: Eine Kulturgeschichte, Edition Leipzig.

Robathan, D. M. (1968). The pseudo-Ovidian de Vetula, Adolf M. Hakkert (Amsterdam).

Schädler, U. (1999). Vom 20-Felderspiel zum Würfelvierschach?, Board Games Studies 2: 144-148.

Schädler, U. (2005). Grabenkämpfe und Eselsbrücken. Grundpositionen der Schachgenese, in E. Meissenburg (ed.), Okkasioneller Rundbrief No. 29, Vindobona, pp. 259-265.

Scharfe, H. (1968). Untersuchungen zur Staatsrechtslehre des Kautalya, O. Harrassowitz.

Scharfe, H. (1989). The State in Indian Tradition, Brill Academic Publisher (Leiden).

Schetelich, M. (1997). Die maṇdala-Theorie in Artha- und Nitiśāstra, in B. Kölver (ed.), Recht, Staat und Verwaltung im klassischen Indien, Schriften des Historischen Kollegs: Kolloquien 30, R. Oldenbourg Verlag, München, pp. 211-236.

Schlingloff, D. (2009). Zur Urgeschichte des Schachspiels. Fakten und Hypothesen, in S. Schönle (ed.), Festschrift for Egbert Meissenburg, Vindobona, pp. 669-679.

Singh, U. (2010). Politics, violence and war in Kamandaka's nitisara, Indian Economic and Social History Review 47: 29-62.

Syed, R. (1993). Das caturanga im Manasollasa und einige Bemerkungen zum Schach in Indien, Beiträge des Südasien-Instituts der HumboldtUniversität zu Berlin, number 6, pp. 93-132. 
Syed, R. (1995). Anmerkungen zu Alter, Ursprung und Urform des Schachs, Beiträge des Südasien-Instituts der Humboldt-Universität zu Berlin, number 8, pp. 63-108.

Syed, R. (2001). Kanauj, die Maukharis und das Caturanga, Förderkreis Schach-Geschichtsforschung e.V., Kelkheim.

Thieme, P. (1962). Chess and Backgammon (Tric-Trac) in Sanskrit Literature, Indological Studies in Honor of W. Norman Brown, American Oriental Society (New Haven), pp. 204-216.

Thieme, P. (1994). Zur Frühgeschichte des Schachs, Vol. 1 of Tübinger Beiträge zum Thema Schach, edited by Hans Ellinger, Promos-Verlag.

Topsfield, A. (1985). The Indian game of snakes and ladders, Artibus Asiae 46: $203-226$.

Topsfield, A. (2006). Snakes and ladders in India: Some further discoveries, Artibus Asiae 66: 143-179.

van der Linde, A. (1874). Geschichte und Litteratur des Schachspiels, Band I, Verlag von Julius Springer.

van der Linde, A. (1881). Quellenstudien zur Geschichte des Schachspiels, Verlag von Julius Springer.

Weber, A. (1873). Enige Daten über das Schachspiel nach indischen Quellen, Monatsbericht der Königlich Preussischen Akademie der Wissenschaften zu Berlin. Gesammtsitzung vom Februar 1872, Buchdruckerei der kgl. Akademie der Wissenschaften, Berlin, pp. 59-89.

Wiese, H. (2012). Backward induction in Indian animal tales, International Journal of Hindu Studies 16: 93-103.

Zimmer, H. (1969). Philosophies of India, Princeton University Press. 